Original Article

\title{
SUITABILITY OF STARCH SYRUPS FOR WINTER FEEDING OF HONEYBEE COLONIES
}

\author{
Piotr Semkiw* \\ Piotr Skubida \\ Research Institute of Horticulture, Apiculture Division, Kazimierska 2,
24-100 Puławy, Poland
*corresponding author: piotr.semkiw@inhort.pl
Received: 19 April 2016; accepted: 27 September 2016
}

Abstract:

Three different starch syrups available on the Polish market for winter feeding of bees were evaluated for two consecutive beekeeping seasons (2012/2013 and 2013/2014). Sugar syrup and inverted sucrose syrup were used as the control. Winter feeding was conducted at two times: earlier and later in the season. After supplementation of winter feeding was stopped, we measured colony strength (number of combs covered by bees) and brood area. After overwintering (spring 2013 and 2014), we estimated the influence of these foods on: bee mortality during overwintering (number of dead bees in winter debris), food consumption, colony strength and brood area in spring (two measurements in three-week intervals), development dynamics and honey yield from spring flow. An analysis of the results for the parameters assessed before overwintering, after its end and during spring development did not show significant differences between bee colonies fed with different types of food. No relevant difficulties concerning food crystallisation were encountered. The analysed syrups turned out to be as suitable for winter feeding of bees as sugar and inverted sucrose syrups.

Keywords: feeding, honeybee colony, hydroxymethylfurfural (HMF) overwintering, starch syrup, sugar syrup

\section{INTRODUCTION}

Natural sources of hydrocarbons for honeybees are nectar and honeydew as well as honey produced from them (Brodschneider \& Crailsheim, 2010). It is necessary to feed the bees, during long periods of adverse weather conditions and when there is no availability of flow or when beekeepers removed the hydrocarbon food from bees during honey harvest and there is no prospect for the flow to occur (Haydak, 1970; Brodschneider \& Crailsheim, 2010). The hydrocarbon food needs to be supplemented because during beekeeping season (from spring to winter feeding) a bee colony should have at least a $5 \mathrm{~kg}$ permanent hydrocarbon supply (Pidek, 1985). A vital condition of the bee colonies to have good overwintering, is a proper winter food supply (Skubida, 1998). The amount of food provided to bees, is a one-time dose and the time of supplying winter supplementation is an important element of the so-called winter feeding of bee colonies (Pidek, 1985; Severson \& Erickson, 1984;
Seeley \& Visscher, 1985; Pedersen, Pedersen, \& Pedersen, 1996; Skubida, 1998). To supply winter food, beekeepers can use sugar syrup, sucrose inverted syrup, starch syrup or high-fructose corn syrup (HFCS) (Jachimowicz \& El Sherbiny, 1975; Skubida, 1998, von der Ohe \& Schönberger, 2002; Liebig, 2005; Ceksteryte \& Racys, 2006; LeBlanc et al., 2009; Brodschneider \& Crailsheim, 2010, Sammataro \& Weiss, 2013; Krainer at al., 2016). Sugar syrup (a mixture of water and pure sucrose from sugar beets or sugarcane) has been used for many years to feed honeybees (Free \& Spencer-Booth, 1961; Barker, 1971; Bobrzecki, 1976; Gromisz, 1985). Sugar syrup results in very good benefits. However, using granulated sugar has some disadvantages, e.g. a necessity for supplying bees with considerable amounts of sugar syrup, the comparatively high cost of sugar, the high cost of sugar syrup preparation (Gromisz, 1985), and the risk of fermentation during long-term storage (Goodwin, 1997; Sammataro \& Weiss, 2013). For all of these reasons, it is necessary to 
search for alternatives. In North America, already in the 1970s, attempts were made to use HFCS as feed for bees (Barker \& Lehner, 1978). Due to its lower price in comparison to sucrose and the properties of the syrup (for instance, microbiological stability due to high osmotic pressure), HFCS usage in beekeeping has increased (Hanover \& White, 1993; Sammataro \& Weiss, 2013). Using HFCS in apiaries provoked different opinions (Barker \& Lehner, 1978; Rinderer \& Baxter, 1980; Severson \& Erickson, 1984; Le Blanc et. al., 2009; Sammataro \& Weiss, 2013). In Western Europe starch syrups used in beekeeping are also called maltose syrups. These syrups have been produced from the cereal starch, mainly wheat starch. One-year studies conducted in the Netherlands positively evaluated the beekeeping applicability of maltose syrups despite observing their partial crystallisation in spring (von der Ohe \& Schönberger, 2002). The Apiculture Department of the University of Hohenheim, Germany, had a positive opinion concerning different maltose syrups used in winter feeding of bee colonies over a 6-year period (Liebig, 2005). In Poland, the first experiments of overwintering bee colonies fed with starch syrup did not give positive results. The long, severe 2005/2006 winter season resulted in considerable crystallisation of the winter supply and substantial losses of colonies in apiaries. Analysis of the supply samples' hydrocarbon composition indicated that the reason for the crystallisation was a high content of glucose (38\%) combined with a relatively low content of fructose (22.1\%). Moreover, overburdening the bee's rectum with maltodextrine poses an additional threat for overwintering bees (Rybak - Chmielewska, Szczęsna, \& Waś, 2006). Despite the situation of 2005/2006, Polish beekeepers interest in starch syrups did not decline. The market offered a broader and broader range of starch products, and their price in comparison to inverted sucrose syrups and the sugar itself was in fact competitive. There was a lack of information on the chemical composition of starch syrups and their suitability with reference to the condition and development of the fed bee colonies during overwintering and in early spring. The only source of information were opinions (often contradictory) of a relatively small group of beekeepers that had used those syrups or data given by manufacturers or distributors of those foods. Undoubtedly, such differences in experienced beekeepers' opinions could have been influenced by other factors, such as colony health, which directly influence the overwintering of bee colonies. That is why, the first aim of this study was to evaluate the suitability of three starch syrups available on the Polish market for winter feeding of bee colonies. Sugar syrup and inverted sucrose syrup were used as the control. The second aim of the study was to verify the influence of delaying the winter feeding of bee colonies on their: overwintering, spring development and honey production.

\section{MATERIAL AND METHODS}

The studies were conducted in two consecutive beekeeping seasons, i.e. 2012/2013 and 2013/2014, in experimental apiaries of the Research Institute of Horticulture, Apiculture Division in Puławy (5124'30.7"N 2158'01.9"E), Poland. These experimental apiaries are located close to one other (a distance of about $3 \mathrm{~km}$ ) in Sadłowice and Nasiłów, in the Puławy District, Poland.

\section{Honeybee colonies}

Bee colonies (Apis mellifera caucasica) with no clinical signs of any disease, were set in wooden Dadant type bee-hives (frame size $435 \mathrm{~mm} \times$ $300 \mathrm{~mm}$ ) and used for the study. Before starting the experiment, bee colonies were evaluated for brood area and strength, so that homogeneous groups could be created (Tab. 1). The bee colony strength was assessed by counting the number of combs with both sides covered by bees. To estimate the amount of brood (opened and capped brood) vertical and horizontal axes of brood combs were measured on each side of the brood combs. To calculate the area $\left(\mathrm{dm}^{2}\right)$, "Tables of Brood Area Measurements" from the Polish Industry Standard BN-81/9148-01 (1982) were applied. In all the experimental colonies, 3 preparations were used for Varroa control. The main treatment, lasting 8 weeks (from the end of August to the beginning of October), was conducted with Biowar 500 (a.i. Amitraz, 500 mg/ 
Table 1

Biological status of the honeybee colonies before starting the winter feeding (average for 2012 and 2013)

\begin{tabular}{cccc}
\hline \multirow{2}{*}{$\begin{array}{c}\text { Feeding } \\
\text { time (n) }\end{array}$} & $\begin{array}{c}\text { Type of syrup - group } \\
(\mathbf{n})\end{array}$ & Brood area (dm²) & $\begin{array}{c}\text { Number of frames covered by } \\
\text { bees }\end{array}$ \\
\cline { 3 - 4 } & Sugar syrup (17) & Mean \pm SD & Mean \pm SD \\
\hline & Apiinvert (17) & $42.3 \pm 10.4$ & $10.5 \pm 1.2$ \\
Early (84) & Apifood (17) & $43.9 \pm 10.7$ & $10.7 \pm 1.4$ \\
& Apikel 20 (17) & $45.3 \pm 8.4$ & $10.6 \pm 1.1$ \\
& Apifortune (16) & $42.9 \pm 9.1$ & $10.5 \pm 1.2$ \\
& * p - value & $40.6 \pm 7.4$ & $10.5 \pm 1.0$ \\
& Sugar syrup (17) & 0.67 & 0.96 \\
\hline \multirow{3}{*}{ Late (80) } & Apiinvert (15) & $4.4 \pm 3.1$ & $6 \pm 0$ \\
& Apifood (16) & $3.9 \pm 4.0$ & $6 \pm 0$ \\
& Apikel 20 (16) & $4.2 \pm 3.9$ & $6 \pm 0$ \\
& Apifortune (16) & $4.0 \pm 3.0$ & $6 \pm 0$ \\
& $*$ * - value & $4.4 \pm 4.0$ & $6 \pm 0$ \\
\hline
\end{tabular}

*ANOVA, $p<0.05$; $n$-number of honeybee colonies in a group; SD - standard deviation

strip, 2 strips per colony). Additional treatment (after removing the strips) was conducted with 2-time (in one-week intervals) fumigation of Apiwarol (a.i. amitraz - $12.5 \mathrm{mg} /$ tablet). When no capped brood was present in the colonies (the middle of November), a 3.5\% solution of oxalic acid (OA) was used to dose $5 \mathrm{ml}$ of the solution per every beeway, on average about 30 - $40 \mathrm{ml}$ per one bee colony.

\section{Winter feeding}

Winter feeding of bee colonies was conducted using 3 starch syrups of different compositions (Apifood - manufactured in Poland, Apikel 20 - manufactured in Germany, Apifortune manufactured in France), 1 inverted sucrose syrup (Apiinvert - manufactured in Germany) (Tab. 2) and a syrup made of beet sugar which we prepared (sugar to water ratio - 5:3). The analysed foods were used over two consecutive seasons (2012 and 2013) two times - early and late in the season. The early feeding started in the middle of August, and ended in the $1^{\text {st }}$ decade of September, while the late feeding begun in the $1^{\text {st }}-2^{\text {nd }}$ decade of September and ended in the $1^{\text {st }}$ decade of October. Bee colonies were fed using frame feeders and the one-time dose was 4 litres. Individual feedings were done in four-day intervals so that the bees could actually intake the syrup and deposit it in the combs' cells. The total one-winter dose per one colony amounted to 16 litres for starch syrups, 17 litres for inverted sucrose and 20 litres for sugar syrup.

\section{Measurements and calculations}

After ending supplementation, the condition of the bee colonies was assessed based on the measurements of strength (number of combs covered by bees) and brood area. After overwintering (spring 2013 and 2014), we evaluated the influence of different foods on: bee mortality during overwintering (number of dead bees in the winter debris), food consumption (calculated as a difference between the amount of food determined in spring and food consumed during winter feeding and expressed as dry matter), colony strength (number of combs covered by bees), brood area in spring (two measurements in three-week intervals), development dynamics (increase in the brood area between measurements), honey yield from spring flows 
Table 2

Physical and chemical properties of the tested syrups - values declared by manufacturers on product labels

\begin{tabular}{ccccc}
\hline & \multicolumn{4}{c}{ Type of syrup } \\
\cline { 2 - 5 } Parameter & Apifood & Apifortune & Apikel 20 & $\begin{array}{c}\text { Apiinvert } \\
\text { Inyry syrups }\end{array}$ \\
\cline { 2 - 5 } & 77.6 & $74-76$ & $72-74$ & 72.2 \\
\hline Dry weight (\%) & $22-28$ & 25 & $16-20$ & 39 \\
Fructose (\%) & $30-37$ & 33.5 & 24 & 31 \\
Glucose (\%) & 0 & 0 & 0 & 30 \\
Sucrose (\%) & $17-24$ & 20.5 & 42 & 0 \\
Maltose (\%) & $5-15$ & 21 & 14 & 0 \\
Maltotriose (\%) & to 40 & nd & to 20 & nd \\
HMF (mg/kg) & & &
\end{tabular}

nd - no data

(evaluation conducted on the turn of May and June) and the degree of supply crystallisation.

\section{Statistical analysis}

Meteorological conditions between seasons were compared using the t-Student's t-test for independent data. Other statistical calculations were done using two-way ANOVA. Means were compared using the post-hoc Tuckey's test for different $n$ numbers. Value $p<0.05$ indicated statistically significant differences. All the statistical calculations were conducted using the Statistica v. 10 software.

=2012/2013 $=2013 / 2014$

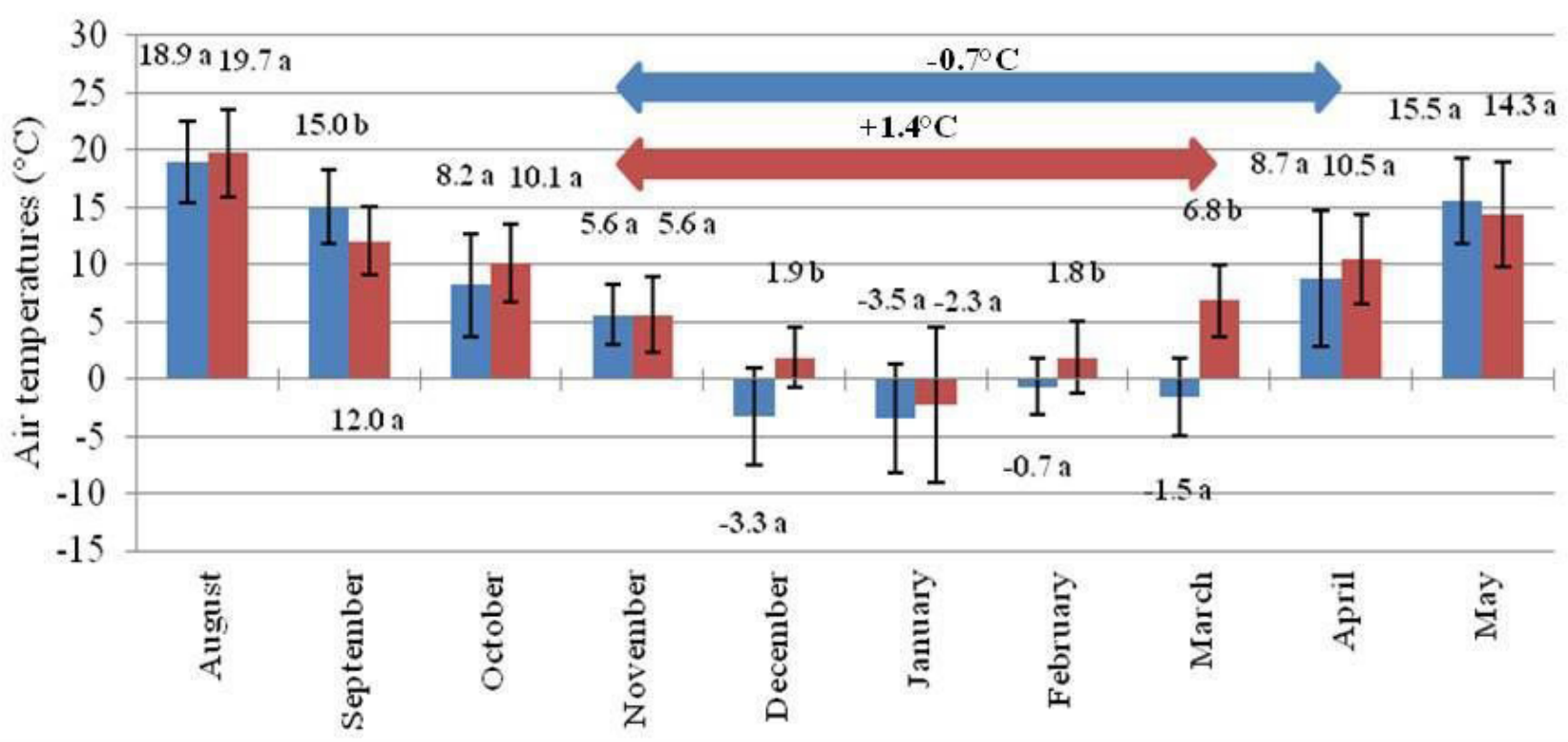

Fig. 1

Mean air temperatures during the study period. Bars indicate standard deviation. Horizontal arrows indicate approximate length of honeybee colonies overwintering. Colour of the arrows indicates different beekeeping seasons according to the legend. 
Table 3

Biological status of the honeybee colonies after the end of winter feeding, before overwintering (average for 2012 and 2013)

\begin{tabular}{|c|c|c|c|}
\hline \multirow{2}{*}{$\begin{array}{l}\text { Feeding } \\
\text { time (n) }\end{array}$} & \multirow{2}{*}{$\begin{array}{c}\text { Type of syrup - } \\
\text { group (n) }\end{array}$} & Brood агеа $\left(\mathrm{dm}^{2}\right)$ & $\begin{array}{c}\text { Number of frames } \\
\text { covered by bees }\end{array}$ \\
\hline & & Mean \pm SD & Mean \pm SD \\
\hline \multirow{6}{*}{ Early(84) } & Sugar syrup (17) & $4.3 \pm 2.9$ & $5.8 \pm 0.4$ \\
\hline & Apiinvert (17) & $4.3 \pm 4.2$ & $5.9 \pm 0.3$ \\
\hline & Apifood (17) & $4.8 \pm 4.3$ & $5.9 \pm 0.3$ \\
\hline & Apikel 20 (17) & $4.9 \pm 3.5$ & $5.8 \pm 0.4$ \\
\hline & Apifortune (16) & $4.7 \pm 3.6$ & $5.7 \pm 0.5$ \\
\hline & ${ }^{\star} p$ - value & 0.86 & 0.47 \\
\hline \multirow{6}{*}{ Later (80) } & Sugar syrup (17) & $2.9 \pm 3.2$ & $5.8 \pm 0.4$ \\
\hline & Apiinvert (15) & $3.4 \pm 3.3$ & $5.8 \pm 0.3$ \\
\hline & Apifood (16) & $2.8 \pm 2.4$ & $5.9 \pm 0.5$ \\
\hline & Apikel 20 (16) & $1.8 \pm 1.7$ & $5.9 \pm 0.3$ \\
\hline & Apifortune (16) & $3.2 \pm 2.3$ & $5.8 \pm 0.3$ \\
\hline & ${ }^{*} p$ - value & 0.53 & 0.91 \\
\hline
\end{tabular}

*ANOVA, $\mathrm{p}<0.05$; $\mathrm{n}$-number of honeybee colonies in a group; SD - standard deviation

Table 4

Number of dead bees in winter debris and consumption of winter food (average for 2013 and 2014)

\begin{tabular}{|c|c|c|c|}
\hline \multirow{2}{*}{$\begin{array}{l}\text { Feeding } \\
\text { time (n) }\end{array}$} & \multirow{2}{*}{$\begin{array}{c}\text { Type of syrup - group } \\
\text { (n) }\end{array}$} & $\begin{array}{c}\text { Number of dead bees in winter } \\
\text { debris }\end{array}$ & $\begin{array}{l}\text { Consumption of winter food } \\
\qquad(\mathrm{kg})\end{array}$ \\
\hline & & Mean \pm SD & Mean \pm SD \\
\hline \multirow{6}{*}{ Early (81) } & Sugar syrup (16) & $717.7 \pm 448.4$ & $12.5 \pm 1.0$ \\
\hline & Apiinvert (16) & $1040.7 \pm 436.5$ & $13.0 \pm 1.4$ \\
\hline & Apifood (17) & $890.3 \pm 539.6$ & $12.8 \pm 1.4$ \\
\hline & Apikel 20 (16) & $981.9 \pm 492.6$ & $12.5 \pm 1.3$ \\
\hline & Apifortune (16) & $920.2 \pm 506.5$ & $12.4 \pm 1.5$ \\
\hline & ${ }^{\star} p$ - value & 0.40 & 0.67 \\
\hline \multirow{6}{*}{ Late (75) } & Sugar syrup (16) & $766.6 \pm 282.4$ & $12.8 \pm 0.9$ \\
\hline & Apiinvert (14) & $1056.3 \pm 452.7$ & $13.7 \pm 0.8$ \\
\hline & Apifood (15) & $1024.3 \pm 602.9$ & $12.8 \pm 1.3$ \\
\hline & Apikel 20 (15) & $994.4 \pm 417.7$ & $13.5 \pm 1.5$ \\
\hline & Apifortune (16) & $1090.7 \pm 583.5$ & $13.0 \pm 1.2$ \\
\hline & ${ }^{*} p$ - value & 0.35 & 0.13 \\
\hline
\end{tabular}




\section{RESULTS}

Meteorological conditions and duration of the overwintering bee colonies

The ambient temperature was registered during the feeding period, overwintering of colonies, and spring development (August - May) using a professional meteorological station Davis Vantage Pro 2 with the Weather Link ${ }^{\circledR}$ IP software. A comparison of mean air temperature between the two studied seasons (2012/2013 and 2013/2014) showed significant differences in September, December, February and March (Fig. 1). In the first year, lower temperatures were especially evident in the winter months. In the first decade of November 2012, the air temperature was low enough for the bees to form the winter cluster. The first intensive spring flights were noted on 12 April 2013, thus, overwintering lasted 151 days. In the second studied season (2013/2014), the cluster was formed in the corresponding period of 2012, although the first spring flights were observed on 11 March 2014, thus, overwintering lasted 121 days. Mean air temperatures during overwintering significantly differed between years: $-0.7^{\circ} \mathrm{C}$ in 2012/2013 and $+1.4^{\circ} \mathrm{C}$ in 2013/2014, $p<0.001$.

\section{Bee colonies}

After ending the winter feeding, the brood area and number of combs covered by bees were evaluated. In bee colonies fed earlier in the season the brood area did not differ statistically depending on the type of food used $(p=0.86)$ and ranged from $4.3 \mathrm{dm}^{2}$ (inverted sucrose syrup, Apiinvert) to $4.9 \mathrm{dm}^{2}$ (Apikel 20) (Tab. 3). Bee colonies were of similar strength $(p=0.47)$ and bees covered from 5.7 combs (Apifortune) to 5.9 combs (Apiinvert, Apifood). Brood area in bee colonies that were fed later was from 1.8 $\mathrm{dm}^{2}$ (Apikel 20) to $3.4 \mathrm{dm}^{2}$ (Apiinvert) and did not differ significantly between groups $(p=0.53)$, the findings were similar for early feeding. Also, no significant differences were found in the number of combs covered by bees $(p=0.91)$.

Biological status of the honeybee colonies in spring after overwintering

Table 5

(average for 2013 and 2014)

\begin{tabular}{|c|c|c|c|c|c|}
\hline \multirow{3}{*}{$\begin{array}{l}\text { Feeding } \\
\text { time (n) }\end{array}$} & \multirow{3}{*}{$\begin{array}{l}\text { Type of syrup - } \\
\text { group (n) }\end{array}$} & \multicolumn{2}{|c|}{ Вrood area $\left(\mathrm{dm}^{2}\right)$} & \multicolumn{2}{|c|}{$\begin{array}{c}\text { Number of frames covered by } \\
\text { bees }\end{array}$} \\
\hline & & Measurement I & Measurement II & Measurement I & Measurement II \\
\hline & & \multicolumn{2}{|c|}{ Mean \pm SD } & \multicolumn{2}{|c|}{ Mean \pm SD } \\
\hline \multirow{6}{*}{ Early (81) } & Sugar syrup (16) & $32.2 \pm 13.5$ & $75.1 \pm 21.3$ & $6.4 \pm 1.2$ & $11.8 \pm 0.7$ \\
\hline & Apiinvert (16) & $31.8 \pm 12.8$ & $72.1 \pm 15.6$ & $6.1 \pm 0.8$ & $11.4 \pm 1.0$ \\
\hline & Apifood (17) & $36.2 \pm 11.7$ & $80.4 \pm 16.7$ & $6.6 \pm 1.1$ & $11.6 \pm 0.8$ \\
\hline & Apikel 20 (16) & $32.7 \pm 13.2$ & $73.8 \pm 11.9$ & $5.9 \pm 1.1$ & $11.8 \pm 0.7$ \\
\hline & Apifortune (16) & $32.1 \pm 14.8$ & $70.4 \pm 15.4$ & $6.1 \pm 1.2$ & $11.5 \pm 0.9$ \\
\hline & ${ }^{*} \mathrm{p}$ - value & 0.86 & 0.47 & 0.37 & 0.62 \\
\hline \multirow{6}{*}{ Late (75) } & Sugar syrup (16) & $37.3 \pm 7.3$ & $78.2 \pm 13.1$ & $6.4 \pm 0.6$ & $11.9 \pm 0.5$ \\
\hline & Apiinvert (14) & $39.4 \pm 9.0$ & $77.6 \pm 19.2$ & $6.1 \pm 0.5$ & $11.6 \pm 0.9$ \\
\hline & Apifood (15) & $39.1 \pm 8.9$ & $76.5 \pm 19.5$ & $6.4 \pm 0.7$ & $11.6 \pm 0.8$ \\
\hline & Apikel 20 (15) & $41.0 \pm 14.8$ & $79.8 \pm 15.2$ & $6.3 \pm 0.7$ & $11.9 \pm 0.5$ \\
\hline & Apifortune (15) & $39.8 \pm 9.8$ & $78.6 \pm 15.9$ & $6.1 \pm 0.5$ & $11.7 \pm 0.7$ \\
\hline & ${ }^{*} p$ - value & 0.89 & 0.91 & 0.29 & 0.62 \\
\hline
\end{tabular}

*ANOVA, $p<0.05 ; n$-number of honeybee colonies in a group; SD - standard deviation 
Table 6

Increase in brood area between the measurements and spring honey production of the honeybee colonies (average for 2013 and 2014)

\begin{tabular}{cccc} 
Feeding & Type of syrup - \\
time (n) & group (n) & Brood area $\left(\mathrm{dm}^{2}\right)$ & Honey production (kg) \\
\cline { 3 - 4 } & & Mean \pm SD & Mean \pm SD \\
\hline & Sugar syrup (16) & $43.0 \pm 17.4$ & $10.8 \pm 1.9$ \\
& Apiinvert (16) & $40.4 \pm 20.2$ & $11.4 \pm 3.0$ \\
& Apifood (17) & $44.2 \pm 16.9$ & $11.3 \pm 3.2$ \\
Early (81) & Apikel 20 (16) & $41.1 \pm 13.0$ & $10.9 \pm 3.3$ \\
& Apifortune (16) & $38.3 \pm 15.9$ & $11.2 \pm 3.7$ \\
& $*$ p - value & 0.87 & 0.89 \\
\hline \multirow{3}{*}{ Late (75) } & Sugar syrup (16) & $40.9 \pm 13.2$ & $11.2 \pm 5.8$ \\
& Apiinvert (14) & $38.2 \pm 14.4$ & $12.3 \pm 5.8$ \\
& Apifood (15) & $37.4 \pm 18.6$ & $11.0 \pm 6.8$ \\
& Apikel 20 (15) & $38.8 \pm 11.9$ & $11.5 \pm 5.3$ \\
& Apifortune (15) & $38.8 \pm 16.5$ & 0.91 \\
\hline
\end{tabular}

*ANOVA, $p<0.05 ; \mathrm{n}$-number of honeybee colonies in a group; SD - standard deviation

An analysis of the effect of the time of feeding depending on the type of syrup used, on the determined parameters, did not show significant differences (brood area $-F_{(4,154)}=0,44, p=0.78$; number of combs covered by bees $-F_{(4,154)}=0.83$, $\mathrm{p}=0.51$ ).

After overwintering, during the first spring inspections (the two years combined) 8 colonies were excluded from further assessment (6 colonies from the experimental groups and 2 from the control) due to losses of queen bees or rearing drones or lack of queens not laying eggs. In reference to the time of feeding, 3 colonies were removed from the group fed earlier and 5 from the group fed later.

At the end of overwintering but before first spring flights, winter bee debris was collected from every colony. The assessment of this debris indicated that the number of dead bees during overwintering in bee colonies fed earlier did not differ statistically depending on the type of food used ( $p=0.40$ ) (Tab. 4). Nevertheless, the smallest number of dead bees in the debris was observed in colonies fed with sugar syrup (about 717 bees) and the highest (about 1040 bees) in the group fed with Apiinvert. Also, among colonies fed later, differences between groups were not statistically significant $(p=0.35)$. Characteristically (similarly to early feeding), the lowest number of dead bees in the winter debris was found in the group fed with sugar syrup (about 766 bees), although, the highest number of dead bees was found in the group fed with Apifortune (about 1090 bees). In general, the time of feeding did not significantly affect bee mortality during overwintering $F_{(4,146)}=0.17$, $p=0.95$. Between the study years, regardless of the food used and the time of feeding, a lower number of dead bees was found in the second experimental year $F_{(1,146)}=12.76$, $p<0,001$.

Consumption of winter foods ranged from 12.4 $\mathrm{kg}$ (Apifortune) to $13.0 \mathrm{~kg}$ (Apiinvert) in the group of colonies fed earlier in the season (Tab. 4). Between the used syrups, no significant differences in consumption were found $(p=0.67)$. During later feeding, consumption of supplies 
between the tested foods was also similar $(p=0.13)$ and ranged from $12.8 \mathrm{~kg}$ (sugar syrup, Apifood) to $13.7 \mathrm{~kg}$ (Apiinvert). Regardless of the used food, bee colonies fed earlier consumed less food during winter in comparison to bee colonies fed later in the season $F_{(1,146)}=6.85$, $\mathrm{p}=0.009$.

During Measurement $\mathrm{I}$, the brood area in bee colonies fed earlier was from $31.8 \mathrm{dm}^{2}$ (Apiinvert) to $32.7 \mathrm{dm}^{2}$ (Apikel 20) and bees covered from 5.9 combs (Apikel 20) to 6.6 combs (Apifood) (Tab. 5). Values obtained for the assessed parameters with reference to the used food were similar (brood area - $p=0.86$; strength $p=0.37)$. Вrood агеa in bee colonies fed later was from $37.3 \mathrm{dm}^{2}$ (sugar syrup) to $41.0 \mathrm{dm}^{2}$ (Apikel 20). In the case of the number of combs covered with bees, these values ranged from 6.1 combs (Apifortune, Apiinvert) to 6.4 combs (sugar syrup, Apifood). At this stage, no significant differences were found for the determined parameters (brood area - $p=0.80$; strength - $p=0.29$ ). The second inspection performed three weeks later, did not indicate any changes in trends observed previously regarding the biological state of bee colonies. Depending on the time of feeding and the type of syrup used, the values of the assessed parameters were similar (brood area - $p=0.91$; strength $-p=0.62$ ). Spring development of bee colonies, estimated based on the increase in brood area between measurements, was similar in all the groups (Tab. 6). Analysis did not show significant differences between different foods $\left(F_{(4,146)}=0.22\right.$, $p=0.93)$, or feeding times $\left(F_{(1,146)}=0.99, p=0.32\right)$. Honey productions from spring flow (willow, maples, orchards, and winter rape) were similar. Bee colonies fed earlier, collected from $10.8 \mathrm{~kg}$ (sugar syrup) to $11.4 \mathrm{~kg}$ of honey (Apiinvert); $p=0.89$. The amount of honey centrifuged from colonies fed later, ranged from $11.0 \mathrm{~kg}$ (Apifood) to $12.3 \mathrm{~kg}$ (Apiinvert); $p=0.91$. A comparison of the parameters of bee colony production regarding the time of winter feeding, did not show statistically significant differences $\left(F_{(4,146)}=0.11, p=0.89\right)$.

\section{Food crystallisation}

No signs of food crystallisation were found in any studied group during inspections directly after overwintering. Low amounts $(<0.2 \mathrm{~kg}$ ) of crystallised supplies were not found in a dozen or so bee colonies (from the experimental and control groups) until the middle of May 2013.

\section{DISCUSSION}

Polish literature concerning beekeeping, reports that an optimal time for ending winter feeding is the middle of September (Wilde, 1998). The reason for sticking to that time is because bees of the winter generation are not involved in preparing winter supplies. Loading the bees with the hard work connected to processing the fed syrup, negatively influences the overwintering colony condition which can additionally increase winter losses (Skubida, 1998). Although in apiaries in which natural flows end with the end of the small-leaved lime or buckwheat flowering period, keeping this time is possible. But in apiaries exploiting late flows, e.g. heather, honeydew, or goldenrod, it is no longer possible. The most important reason for conducting our experiment was to evaluate beekeeping suitability of the ready-to-use foods recommended for winter feeding of bee colonies. However, we also wanted to check whether conducting winter feeding in a period when the colony already contains only bees of the winter generation (late feeding) would have any negative implications. This concerns negative implications connected to overwintering and spring development in comparison to colonies fed earlier when the end of feeding, in accordance with practical guidelines, is in the middle of September.

One of the basic disadvantages of the readyto-use foods used in feeding bees, irrespective of the food type (inverted sucrose, starch) is the content of 5-hydroxymethylfurfural, also called HMF, which is harmful for bees (Jachimowicz \& El Sherbiny, 1975; LeBlanc et al., 2009). This compound is created in the production process of these foods, and the amount of this compound depends on the temperature and acidity of the environment (Кrainer et al., 2016). A high concentration of HMF in products used to feed bees can upset the proper functioning of 
bee colonies (Van der Zee \& Pisa, 2010). Storage conditions have a crucial impact on the safety of these foods for bees. A high content of HMF was found (even up to $102.3 \mathrm{ppm}$ ) in syrups stored for a long time outside in the location exposed to high ambient temperatures, while in fresh syrups, the content of this compound was low (Ruiz-Matute et. al., 2010). Similar observations can be made based on the studies of Le Blanc et al. (2009). The HMF content in fresh HFCS of different manufacturers ranged from 3.1 to $28.7 \mathrm{ppm}$. After storing for 36 days at a temperature of $49^{\circ} \mathrm{C}$, the content of HMF in some samples exceeded $200 \mathrm{ppm}$. In samples stored at a temperature of $69^{\circ} \mathrm{C}$, the content of HMF exceeded 30000 ppm. Foods used in our study were stored in a utility room with low ambient temperatures (up to $15^{\circ} \mathrm{C}$ ) from the moment of purchase until used in apiaries (no longer than two months). Thus, it can be assumed that the HMF content in these products did not change significantly in comparison to the initial values. According to information on the labels, the syrups used in our study contained from 20 to 40 ppm of HMF. For two products (Apifortune and Apiinvert) no information on the HMF content was given, nevertheless, we cannot exclude HMF content in these products. We have not evaluated the foods under laboratory conditions. Our experiment was conducted in real apiaries and on a high number of bee colonies. This means that the potential harmful effect of these syrups could be observed in reference to the problems connected to bee colony conditions at the stage of: preparing the colonies for overwintering, after overwintering, and during spring development. As it turned out, we found no signs of a negative impact of starch or inverted sucrose syrups on colony condition. The results of autumn measurements conducted in the experimental colonies did not differ from the results obtained in the control colonies. After overwintering, parameters indicating the condition of overwintered colonies, that is the number of dead bees in the winter debris, brood area, and brood area's increase in spring, and number of combs covered by bees, were similar to the results obtained in the group fed with sugar syrup. Thus, similar to the findings of Severson \& Erickson (1984), we did not find any negative effects of starch syrups on the bees' condition after overwintering. Although Severson \& Erickson (1984) and Sammataro \& Weiss (2013) found a slightly lower brood production in spring in colonies fed with HFCS in comparison to colonies fed with sugar syrup, we did not observed such differences. The results of our studies were similar to observations made in the Netherlands and Germany (von der Ohe \& Schönberger, 2000; Liebig, 2005). Only a slight and statistically insignificant difference was observed in the number of dead bees found in the winter debris. Regardless of the time of feeding, the lowest number of dead bees was always found in colonies fed with sugar syrup. It is difficult to name the direct reason for this. Maybe it is an effect of some maltodextrins in winter food produced from starch syrups (Rybak - Chmielewska, Szczęsna, \& Waś, 2006) or HMF content in the used foods. The latter seems to be the more probable explanation because Apiinvert does not contain maltodextrins, and the number of dead bees in colonies fed with this syrup was similar to the number of dead bees in colonies fed with starch syrups. On the other hand, the number of dead bees in proportion to colony strength in spring, in all the groups, was low enough that it had no significant influence on the development parameters or honey production. Our studies in apiaries prove the hypothesis that a HMF which does not exceed $40 \mathrm{ppm}$, is safe for bee colonies. Crystallisation of the winter supply can pose a significant threat for overwintering bee colonies. According to Konopacka (2006), for the winter food not to crystallise, fructose should predominate over glucose in the composition of sugars, and their quantitative ratio (F/G) should be higher than 1. The most beneficial ratio exceeds 1.26. Based on the data from product labels, starch syrups used in our study had an initial fructose to glucose ration below 0.8. Moreover, the starch syrups used in our study contained significant amounts of maltose. As a result of bee enzyme action, maltose can be transformed into two molecules of glucose additionally lowering the 
F/G ratio of the winter supply, thus increasing the risk of their crystallisation. However, as a result, we found trace amounts of crystallised food in the residues of winter supplies in May 2013. This was found in colonies fed with starch syrups as well as in groups fed with Apiinvert and sugar syrup. The scale and range of crystallisation of winter supplies did not influence the results of overwintering and spring development of bee colonies. Undoubtedly, winter conditions during the years when our studies were conducted differed significantly from the winter season 2005/2006 when huge losses of colonies in apiaries fed with starch syrup were found (Rybak - Chmielewska, Szczęsna, \& Waś, 2006). During that winter, temperature drops below $-20^{\circ} \mathrm{C}$ occurred and lasted several days. Therefore, that winter has been classified within the ten most severe winters of the last century in Poland.

Delaying the winter feeding by a month did not result in any negative effects in contrast to previous opinions (Skubida, 1998; Wilde, 1998). All of the syrups, despite a late feeding time (colonies fed later) were willingly consumed by bees and deposited in combs. Four-day intervals were enough for the bees to completely drain the feeders. In the case of sugar syrup or inverted sucrose syrup, due to lower viscosity in comparison to starch syrups, the food was usually consumed after just 2 days. Colonies overwintered well and their condition did not differ from the condition of colonies fed earlier. Lower consumption of foods during winter by colonies fed earlier, resulted from the fact that during winter feeding the goldenrod (Solidago spp.) flow was still available. Thus, the amount of the winter supply was increased by the honey collected from this flow. Whereas bee colonies fed later, consumed the goldenrod honey supplies before the start of winter feeding.

The results of our study indicated that starch syrups used for winter feeding turned out to be as suitable as the so far used sugar syrup or inverted sucrose syrup. No significant differences in the condition of bee colonies were observed before overwintering, after overwintering, and during spring development. No sig- nificant cases of winter supply crystallisation were found. Delaying the time of feeding had no influence on the condition of overwintering colonies, nor their spring development or exploitation of available flows, when compared to colonies fed earlier.

\section{AKNOWLEDGEMENTS}

The authors would like to extend their thanks to dr hab. Zbigniew Kołtowski - head of the Laboratory of Plant Pollination of the Research Institute of Horticulture, Apiculture Division in Puławy, Poland, for collecting the meteorological data and enabling the data to be used in this paper.

\section{REFERENCES}

Barker, R. (1971). Shouldn't a minimum food supply be specified for bee colonies rented for pollination? Gleanings in Bee Culture, 99,299-315.

Barker, RJ, \& Lehner, Y. (1978). Laboratory comparison of high fructose corn syrup, grape syrup, honey, and sucrose syrup as maintenance food for caged honey bees. Apidologie, 9, 111-116.

BN-81/9148-01. (1982). Norma branżowa. Rodzina pszczela [Industry Standard. Honeybee colony]. Wydawnictwo Normalizacyjne Warszawa.

Bobrzecki, J. (1976). Rozwój i produkcyjność rodzin pszczelich zimowanych na różnych pokarmach węglowodanowych [Development and productivity of bee colonies wintered on the different carbohydrate stores]. Zeszyty Naukowe ART w Olsztynie, 19,43-92

Brodschneider, R, \& Crailsheim, K. (2010). Nutrition and health in honey bees. Apidologie, 41, 278-294. http://dx.doi.org/10.1051/apido/2010012

Ceksteryte, V., \& Racys, J. (2006). The quality of syrups used for bee feeding before winter and their suitability for bee wintering. Journal of Apicultural science, 5a1), 5-14.

Free, JB., \& Spencer-Booth, Y. (1961). Effect of feed- 
ing sugar syrup to honey-bee colonies. Journal of Agricultural Science, 57, 147-151. http://dx.doi. org/10.1017/S0021859600047614.

Goodwin, RM. (1997). Feeding sugar syrup to honey bee colonies to improve pollination: a review. Bee World, 78, 56-62. http://doi.org/10.1080/000577 2X.1997.11099335

Gromisz, M. (1985). Gospodarka cukrem w pasiekach polskich. Pszczelnicze Zeszyty Naukowe, 29, 323338.

Hanover, L.M., \& White, J.S. (1993). Manufacturing, composition, and application of fructose. The American Journal of Clinical Nutrition, 58 (5 Suppl), 724S7325

Haydak, M.H. (1970). Honey bee nutrition, Annual Review of Entomology, 15, 143-156.

Jachimowicz, T., \& El Sherbiny, G. (1975). Zur Problematik der Verwendung von Invertzucker für die Bienenfütterung. Apidologie, 6(2), 121-143

Konopacka, Z (2007). Pokarmy do uzupełnienia zimowych zapasów rodzin pszczelich. Pszczelarstwo, 7,2-4.

Krainer, S., Brodschneider, R., Vollmann, J., Crailsheim, K., \& Riessberger-Galle, U. (2016). Effect of hydroxymethylfurfural (HMF) on mortality of artificially reared honey bee larvae (Apis mellifera carnica). Ecotoxicology, 25, 320-328. http://doi.org/10.1007/s10646-015-1590-x.

LeBlanc, BW., Eggleston, G., Sammataro, D., Cornett, C., Dufault, R., Deeby, T., \& Cyr, ES (2009). Formation of hydroxymethylfurfural in domestic high- fructose corn syrup and its toxicity to the honey bee (Apis mellifera). Journal of Agricultural and Food Chemistry, 5716), 7369-7376. http://pubs.acs.org/doi/ abs/10.1021/jf9014526

Liebig, G., (2005). Getreidestärkesirup: besser als sein Ruf. Deutsches Bienen Journal, 13(8), 18-19.

Pedersen J., Pedersen G., \& Pedersen E. (1996). Outside wintering of single brood chamber hives revis- ited. American Bee Journal, 3, 181-185

Pidek, A. (1985). Próba zimowania rodzin pszczelich na zmniejszonych zapasach węglowodanowych. Pszczelnicze Zeszyty Naukowe, 29, 133-144.

Rinderer, TE., \& Baxter, JR. (1980). Honeybee hoarding of high fructose corn syrup and cane sugar syrup. American Bee Journal, 120,817- 818.

Ruiz-Matute, Al., Weiss, M., Sammataro, D., Finely J., Sanz ML (2010). Carbohydrate composition of highfructose corn syrups (HFCS) used for bee feeding: effect on honey composition. Journal of Agricultural and Food Chemistry, 58, 7317-7322. http://pubs. acs.org/doi/abs/10.1021/jf100758x

Rybak-Chmielewska, H., Szczęsna, T., \& Waś, E. (2006). Attempt to assay maltodextrins occurring in starch syrup and in winter stores made by bees from that syrup. Journal of Apicultural Science, 502), 127-135

Sammataro, D., \& Weiss, M. (2013). Comparison of productivity of colonies of honey bees, Apis mellifera, supplemented with sucrose or high fructose corn syrup. Journal of Insect Science, 13(19), 1-13. http://dx.doi.org/10.1673/031.013.1901.

Seeley, T.D., \& Visscher, P.K. (1985). Survival of honeybees in cold climates: the critical timing of colony growth and reproduction. Ecological Entomogy, 10, 81-88.

Severson, D.W., \& Erickson, E.H. (1984). Honey bee (Hymenoptera: Apidae) colony performance in relation to supplemental carbohydrates. Journal of Economic Entomology, 77, 1473-1478.

Skubida, P. (1998). Wpływ zróżnicowanego sposobu przygotowania zapasów zimowych na rozwój i produkcyjność rodzin. Pszczelnicze Zeszyty Naukowe, $42(1), 95-117$.

Statistica ver. 10 (2011). StatSoft, Inc.

Van der Zee R, \& Pisa, L (2010). Bijensterfte 200910 en toxische invertsuikersiroop. Nederlands Cen- 
trum Bijenonderzoek. Rapport 02, 1-15. Retrieved March, 15, 2016, from http://www.beemonitoring. org/Downloads/Bijensterfte\%202009-10_en\%20 toxische_\%20invertsuikersiroop.pdf.

Von der Ohe, W., \& Schönberger H. (2002) Bienenernährung: Futtersirup im Vergleich. Bienenvater. $123(9), 11-15$.

Wilde, J. (1998). Gospodarka pasieczna. In: Pszczelnictwo. (pp. 372-426). Szczecin: Wydawnictwo Promocyjne "Albatros". 